\title{
Field dodder life cycle and interaction with host plants
}

\author{
Marija Sarić-Krsmanović ${ }^{1 *}$ and Sava Vrbničanin ${ }^{2}$ \\ ${ }^{1}$ Institute of Pesticides and Environmental Protection, Banatska 31b, 11080 Belgrade \\ ${ }^{2}$ University of Belgrade, Faculty of Agriculture, Nemanjina 6, 11080 Belgrade \\ ${ }^{*}$ Corresponding author:marijasaric.msaric@gmail.com
}

Received: 22 June, 2017

Accepted: 5 July, 2017

\begin{abstract}
SUMMARY
Field dodder is a parasitic plant that attaches to stems and leaves of broadleaf plants, including weeds, field crops, vegetables and ornamentals, across most agricultural regions of the world. Effective field dodder control is extremely difficult to achieve due to the nature of attachment and close association between the host and the parasite, which require a highly effective and selective herbicide to destroy the parasite without damaging its host. To establish a strategy for controlling parasite growth and restricting the spread of field dodder in crop fields, it is important to learn more about this weed, its life cycle and development.
\end{abstract}

Keywords: Field dodder; Cuscuta; Life cycle; Host plants

\section{INTRODUCTION}

Plants of the genus Cuscuta (common name: dodder) are obligate holoparasitic species. Dodders are the most important group of parasitic weeds in the world, inhabiting virtually every continent and causing sweeping damage to both crop and non-crop species (Dawson et al., 1994). The field dodder is a parasite with a wide spectrum of hosts. Most field dodders are polyphagous species, parasitizing cultivated crops (e.g. Medicago sativa, Beta vulgaris, Allium cepa, Allium sativum, Capsicum annum, Cucumis sativus, Cucurbita pepo, Daucus carota, Lactuca sativa, Lycopersicum esculentum, Nicotiana tabacum), as well as weed and wild flora (e.g. Amaranthus retroflexus, Polygonum aviculare, Chenopodium album, Ambrosia artemisiifolia, A. trifida, Matricaria chamomilla, Solanum nigrum, Xanthium strumarium, etc.) (Kojić \& Vrbničanin, 2000; Vrbničanin et al., 2013). Most of the damage caused by these parasitic flowering plants results from the fact that parasitism is the most acute form of negative interaction between vascular plants in which one of the partners becomes a heterotroph living at the expense of the other, its host. Field dodder infestation leads to gradual weakening of its host plants, reduced lushness of growth and very limited vegetative and generative yield (Koskela et al., 2001). Damage caused this way may eventually cause total destruction of the host plant.

There is no single technology to control this parasitic weed (Joel et al. 2007; Parker, 2009). Newly ploughed fields run a high risk of invasion unless care is taken to prevent introduction of parasitic weed seeds and farmers (and others) educated to be on alert for new infestation (Panetta $\&$ Lawes, 2005). The only way to cope with parasitic weeds is through an integrated approach, employing a variety of measures in a concerted manner, starting with containment 
and sanitation, direct and indirect measures to prevent damage caused by parasites, and finally eradicating the parasite seedbank in soil. To establish strategies to control parasitic growth and restrict the spread of field dodder in crop fields, it is important to learn more about this weed, studying its life cycle and development.

\section{BIOLOGICAL AND ECOLOGICAL CHARACTER OF FIELD DODDER}

Autotrophic flowering plants constitute the predominant group among weed species but weeds also include some semiparasitic and parasitic flowering plants. Parasitic plants are represented by approximately 4200 species classified into 274 genera, which make a little more than $1 \%$ of all flowering plants. Only some $11 \%$ of all genera include species that may be considered as parasites of cultivated plants. The worst economic damage in important host crops is caused by species in only four genera: Cuscuta, Arceuthobium, Orobanche and Striga (Nickrent, 2002). The genus Cuscuta L. (dodders) is one of the most diverse and challenging groups of parasitic plants with more than 200 species and over 70 varieties (Yuncker, 1932; Garcia \& Martin, 2007; Stefanovic et al., 2007).

The stem of a field dodder plant is threadlike and coiling, either leafless or with leaves that are reduced to hardly visible scales. Fully matured field dodder seeds fall off and accumulate on the ground. They may then either germinate during the following season if a suitable host plant is growing in the vicinity or may stay dormant until such conditions have occurred (Swift, 1996). These stem parasites attach to the host by haustoria and depend entirely (or nearly so) on their hosts for the necessary water and nutrient supplies (Kuijt, 1969;
Press \& Phoenix, 2005). At an appropriate moment of maturation, a field dodder plant forms inflorescences with abounding hermaphrodite and actinomorphic flowers (Figure 1a). The flowers are hermaphroditic, tiny, mostly white, redish or yellow. Petals are either individual or coalescent. The corona is bell-shaped or round, mostly with four or five petals. The flower has five stamens. The fruit is a pod containing 1-4 seeds. The seed is tiny, spherical, rough and light brown (Figure 1b). Seeds of this parasitic flowering plant germinate on soil surface from May throughout June. Field dodder is a thermophylic species and its optimal temperature for germination is $30^{\circ} \mathrm{C}$ (Sarić-Krsmanović et al., 2013b). Dodder seeds retain vitality in soil over more than 10 years. A single plant is able to produce up to 15.000 seeds, and their abundance constitutes the main mode of survival of that parasite in the environment (Benvenuti et al., 2005). Its reproduction may also be vegetative through segmentation of its treadlike stem. Such reproduction mode is frequent in alfalfa and clover crops after harvest and haying, which enables its transfer from infested plots to non-infested fields (Parker, 1991).

Cuscuta campestris is considered the most widespread Cuscuta species globally. Even though North America is assumed to be its place of origin, the species is cosmopolitan and very widespread throughout South America, Europe, Asia, Africa and Australia (Holm et al., 1997). Distribution and frequency of Cuscuta species in anthropogenic habitats in Serbia (various types of crops and ruderal habitats in urban and rural areas) have been researched by Vrbničanin et al. (2008), and they detected their presence in $25 \%$ of the assessed 10x10 km squares on the UTM (Universal Transverse Merkator) grid. About 10 Cuscuta species have been detected in Serbia, including the most frequent Cuscuta campestris (Kojić \& Vrbničanin, 2000).

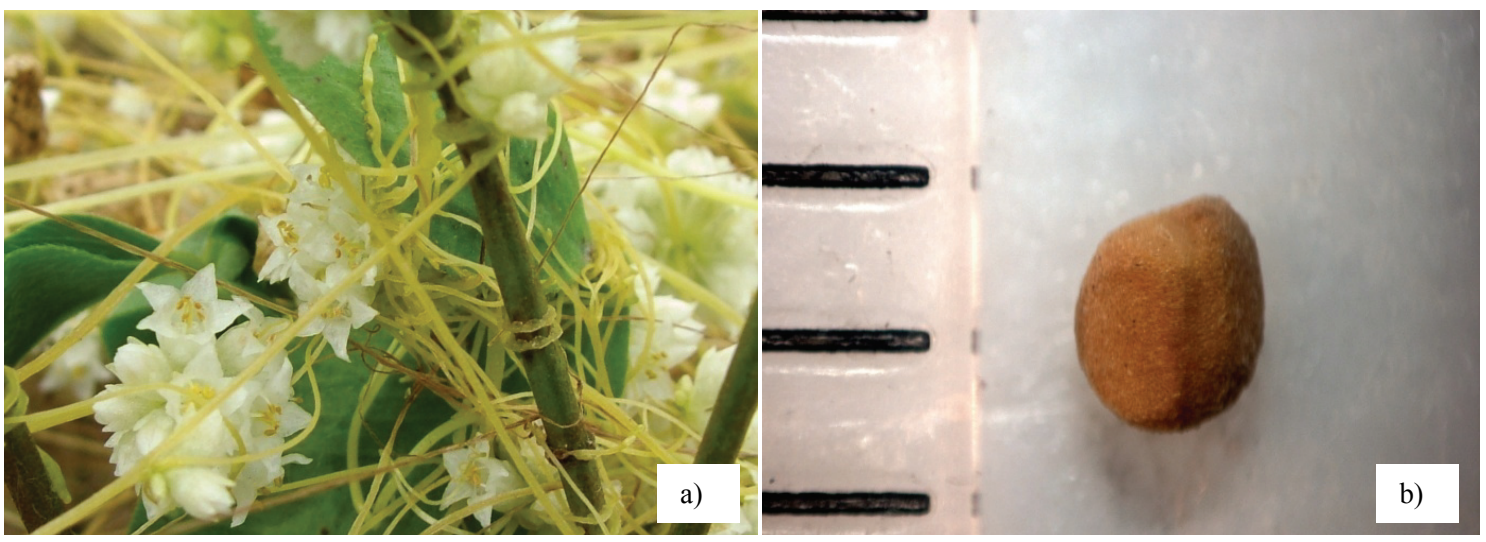

Figure 1. (a) Coiling stems and flowers of field dodder (Cuscuta campestris Yunk) (S. Vrbničanin); (b) seed of field dodder (C. campestris Yunk.) (Sarić-Krsmanović, 2013) 


\section{CUSCUTA LIFE CYCLE}

Steps in the life cycle of plant parasites include: (1) seed germination; (2) early seedling development; (3) search for a host plant, haustorium induction and invasion of the host, haustorium maturation; and (4) interaction with the host plant (Stewart \& Press, 1990; Yoder, 1999).

\section{Seed germination and search for a host}

As in all other angiosperms, the life cycle of Cuscuta plants begins with seed germination. Germinating Cuscuta seedlings depend on limited seed reserves, they are unable to survive alone for a long time and must find an appropriate host plant stem within a few days (Runyon et al., 2006). Cuscuta seedlings normally live less than 3 weeks before becoming parasitic.

Seed dormancy is an important feature of $C$. campestris that ensures its survival as a parasite of crops (Hutchison $\&$ Ashton, 1980). There are three different types of seed dormancy (morphological, physical and physiological), at least two of which have evolved on several specific occasions (Baskin \& Baskin, 1998). Dormancy of $C$. campestris occurs owing to its hard seed coat (Lyshede, 1992). The percentage of hard seeds at dispersal varies among C. campestris (Hutchison \& Ashton, 1979) and C. chinensis plants (Marambe et al., 2002). Dormancy can be broken by the activity of soil microorganisms or by tillage, causing scarification of seed coat (Haidar et al., 1999). The dynamics of germination of $C$. campestris depends on a double mechanism of dormancy. After a period of primary dormancy (additional maturation caused by coat impermeability), the seed goes into an annual cycle of secondary dormancy. In C. campestris, secondary dormancy occurs at the end of summer and it prevents germination during the following autumn and winter in order to avoid the season in which potential hosts of the temperate region would be scarce due to low temperatures. Secondary dormancy ends at the end of winter when temperature begins to grow and overall conditions for germination and growth of host plants improve (Benvenuti et al., 2005). Physical dormancy has been reported for seeds of several Cuscuta species: C. campestris (Benvenuti et al., 2005; Hutchison \& Ashton, 1980), C. trifolii (Lados, 1999), C. monogyna and C. planiflora (Salimi \& Shahraeen, 2000), C. chinensis (Marambe et al., 2002), C. gronovii, C. umbrosa, C. epithymum and C. epilinum (Costea \& Tardif, 2006). However, it is not common for Cuscuta pedicellata (Lyshede, 1984) because seeds of that species are readily water permeable due to a specific structure of their epidermis and endosperm.

To find and attach to potential hosts, Cuscuta plants recognize plant volatiles as chemo-attractants which guide seedling growth and increase the chances of successful establishment of a connection (Runyon et al., 2006). However, expert options vary as to what is the necessary impulse for germination of field dodder seeds. Some researchers (Vail et al., 1990; Benvenuti et al., 2002) believe that Cuscuta spp. do not require host-root exudates to stimulate germination, similar to some important holoparasitic weeds of the genus Orobanche and some hemiparasitic weeds in the genus Striga. Field dodder as a stem parasite is strongly impacted by light signals, which stimulate germination of its seeds (Orr et al., 1996; Tada et al., 1996; Haidar, 2003). Field dodder seedlings tend to grow in the direction of light source, primarily red/ far red light, which help them find hosts, while far red and blue light have a significant role in prehaustoria formation. Recognition of a host occurs through phototropic mechanisms, and some authors claim that chemotropism (movement induced by chemical stimulus) and thigmotropism (movement induced by mechanical stimulus, i.e. by touch) have equally important roles in host recognition process (Haidar et al., 1997). Runyon et al. (2006) found that volatile chemical substances were also important for movement of Cuscuta campestris seedlings in the dark.

\section{Haustorium induction and invasion of the host}

An ability to form specialized organs for absorption, i.e. haustoria (Figure 2), is the chief adaptive property of all higher parasitic plants (Hibberd \& Jeschke, 2001). In field dodder plants, such structures are created from the stem meristem tissue of a parasitic plant and they are considered as modified adventive roots (Swift, 1996). Haustoria may develop even when no potential host is around (Tsivion, 1981; Tada et al., 1996; Ihl \& Wiese, 2000). The main stimulus for developing haustorial tissue may be simply the contact with another surface, such as glass (Rath \& Mohanty, 1987; Tada et al., 1996), filter paper or plastic for example (Beliz, 1986).

The development of haustoria may be roughly differentiated into three stages (Piehl, 1963): (1) attachment (i.e. establishing of a connection with the host tissue); (2) penetration (insertion into the host tissue) and (3) conductive stage (transmission of nutrients). 


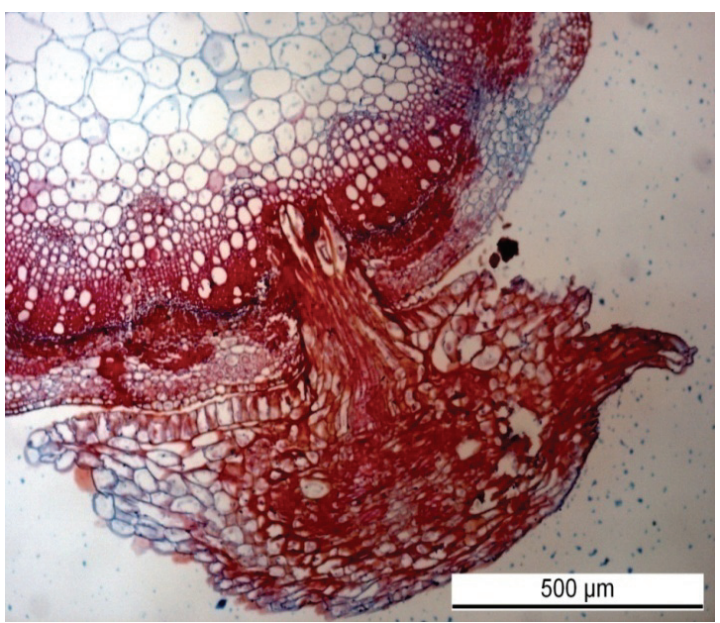

Figure 2. Haustorium of Cuscuta campestris (Sarić-Krsmanović, 2013)

Sharp pointed haustoria develop from appressoria that enable the parasite to draw organic and mineral substances from its host. Obligate parasites are unable to develop without assimilates drawn from their host plants because they are unable to perform photosynthesis (Kuijt, 1969; Losner-Goshen et al, 1998) or their photosynthetic capacity is very weak (Hibberd \& Jeschke, 2001). Even though dodder plants possess a functional photosynthetic apparatus within a ring of cells surrounding vascular tissue (Hibberd \& Jeschke, 2001) the amount of organic matter produced there is too small to provide for the plant sufficiently, so that $99 \%$ of the required carbon is still drawn from the host (Jeschke et al., 1994).

After finding an appropriate host plant, the first physical contact initiates the attachment phase, in which epidermal and parenchymal cells of the parasite begin to differentiate into a secondary meristem and develop prehaustoria, also known as the adhesive disk (Dörr, 1968; Heide-Jørgensen, 1991). Important signals initiating and controlling this prehaustoria formation include mechanical pressure, osmotic potential, and phytohormones, such as cytokinins and auxin (Dawson et al., 1994; Runyon et al., 2010). The prehaustorial cells start to produce and secrete adhesive substances, such as pectins and other polysaccharides, reinforcing the adhesion (Vaughn, 2002). During the attachment phase, host cells in the proximity of Cuscuta haustoria respond with an increase in cytosolic calcium, detectable in host plants using aequorin as calcium reporter. Within the initial several hours of contact, Cuscuta also induces the host plant to produce its own sticky substances, such as arabinogalactan proteins, to promote adhesion (Albert et al., 2006). These glycoproteins are secreted by the host plant and localized to the cell-wall where they can force the adhesion together with other sticky components such as pectins.

The attachment phase is followed by penetration as prehaustoria develop into parasitic haustoria that penetrate the host stem through a fissure. This breach is effected by mechanical pressure (Dawson et al., 1994) and is supported by biochemical degradation of host cell walls caused by secreted hydrolytic enzymes such as methylesterases (Srivastava et al., 1994) or complexes of lytic enzymes consisting of pectinases and cellulases (Vaughn, 2003). Cells at the tip of the invading haustoria form "searching hyphae" which try to reach phloem or xylem cells of the host plant's vascular bundles (Figure 3). A day or two later, epidermal cells of "interior haustoria" begin to elongate and form unicellular structures known as hyphae. In a compatible host, the hyphae searching for vascular

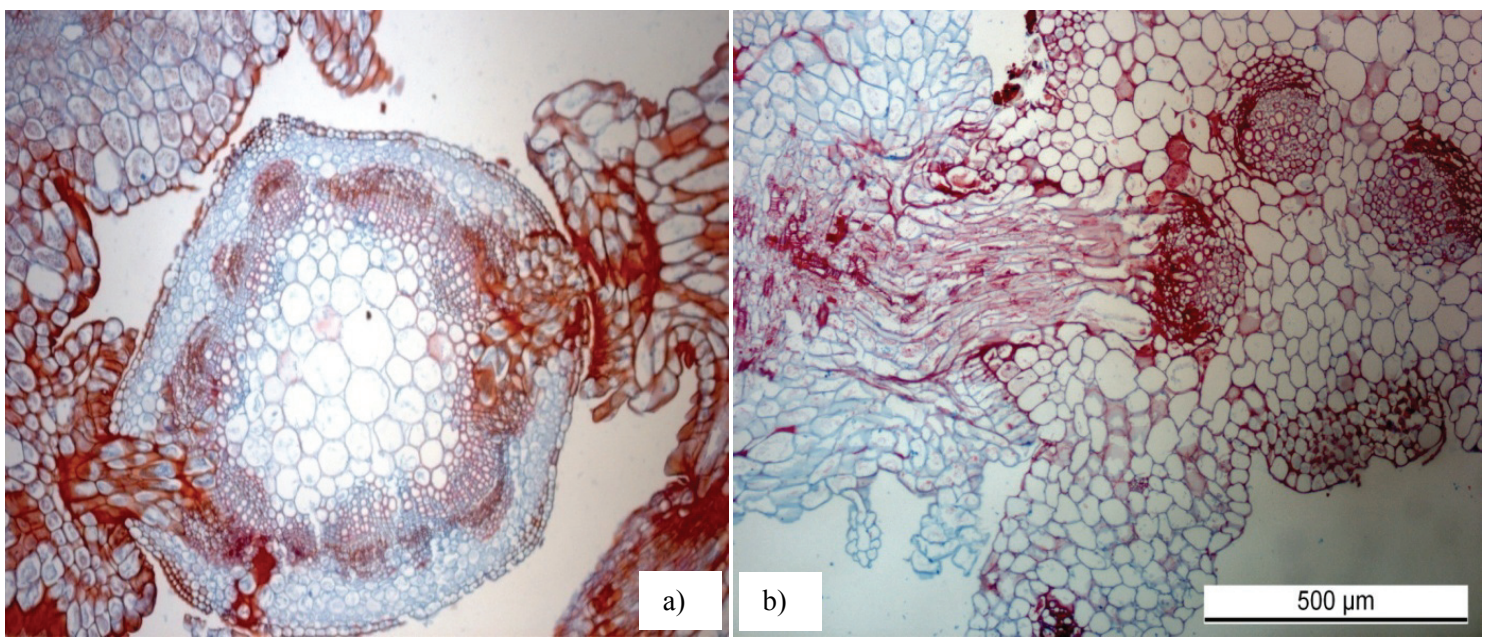

Figure 3. Haustorium "searching hyphae" of field dodder establishing a connection with both phloem and xylem tissues of alfalfa stem (a) and sugar beet petiole (b) (Sarić-Krsmanović, 2013) 
tissue are able to expand from 800 to $2000 \mu \mathrm{m}$ (Dawson et al., 1994; Vaughn, 2003), and their inter- and intra-cellular expansion into the host tissue depends on the mechanical, as well as enzymatic processes (Dawson et al., 1994). These parasitic cells have been described as having ambivalent characters, functioning both as sieve elements and transfer cells (Dörr, 1968, 1969; Dawson et al., 1994). Interestingly, during this process, chimeric cell walls of host and parasite constituents are formed, and interspecific plasmodesmata build up a cytoplasmic syncytium between Cuscuta and its host plant (Haupt et al., 2001; Vaughn, 2003; Birschwilks et al., 2006). To form a connection to the xylem, parasitic and host cells of the xylem parenchyma commence a synchronized development, fusing to build a continuous xylem tube from the host to the parasite (Dörr, 1972). With functional connections to the xylem and phloem of its host, the parasitic plant is supplied with water, nutrients, and carbohydrates (Jeschke et al., 1994; Hibberd et al., 1999; Hibberd \& Jeschke, 2001).

\section{Consequences of field dodder and host interaction}

Transfer of fluids from the host to the parasitic plant occurs across a bridge created between the two organisms utilizing the difference in water potential of cell sap between the two plants. Parasitic flowering plants have a higher negative osmotic potential of cell sap that allows them to uptake organic nutrients from the host plant. In other words, the phloems within vascular bundles of the parasite and the host become connected, creating a "physiological bridge" between the two plants' vascular tissues (Hibberd \& Jeschke, 2001).
As Cuscuta has no roots and no effective photosynthetic system, most nutrients apparently come from the host phloem, but dodder haustoria reach into the xylem too in search of nutrients such as calcium. This makes Cuscuta a phloem feeder, and Haupt et al. (2001) used fluorescent proteins to show a symplasmic connection with companion cells of the phloem. A lower phloem flux here causes a reciprocal interaction between the host and the parasite. In certain cases, Cuscuta can be a mediator of virus infection for the host plant. Apoplasmic and symplasmic connections are found sporadically. The presence of a plasmodesmata connection between Cuscuta and host plant was shown by Birschwilks et al. (2006). However, field dodder has been reported to get not only organic matter from its host through the phloem but minerals too, such as nitrogen, magnesium and calcium, although they are to be found in greater amounts in the xylem than in the phloem (Hibberd \& Jeschke, 2001). Field dodder parasitism interferes with a balance of contents of nitrogen, phosphorus, potassium, organic and inorganic matter in the host plant (e.g. alfalfa or sugar beet) (Sarić-Krsmanović et al., 2013a). It exhausts the host plant, so that it becomes weak, its lushness of growth declines, and fruit and seed maturation become significantly reduced (Wolswinkel, 1974). Also, host plants change their habit as their axillary buds sometimes become suppressed (Tsivion, 1981), and the harm may result in total plant destruction (Figure 6).

Significant changes can be detected in plant morphology and anatomy, so that field dodders cause changes in the anatomy of stalks (epidermis, cortex, pith, diameter) (Figures 4 and 5) and leaves (upper epidermis, palisade tissue, spongy tissue, leaf mesophyll, underside epidermis, vascular bundle cells) of the host plants (Sarić-Krsmanović et al., 2012, 2016; Matković et al., 2012).
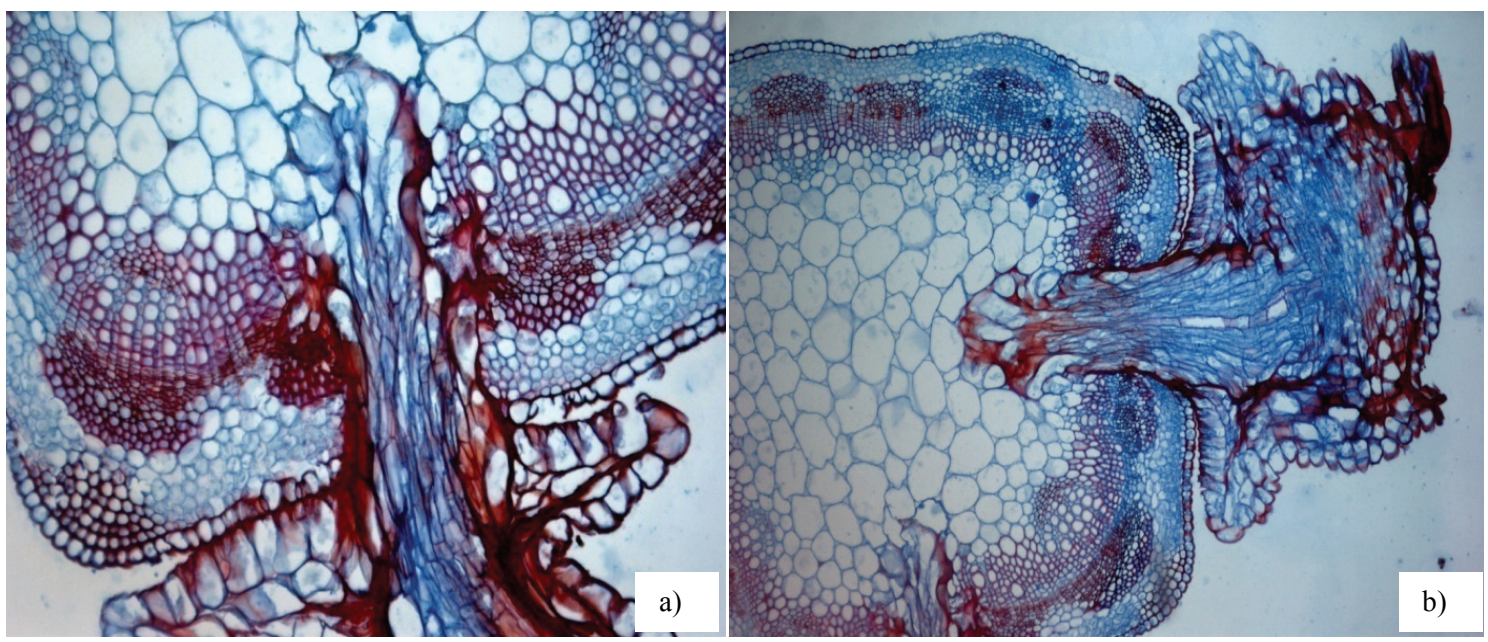

Figure 4. Haustorium "searching hyphae" of field dodder connecting to the central cylinder (pith) tissue of alfalfa stem (a), (b) (Sarić-Krsmanović, 2013) 

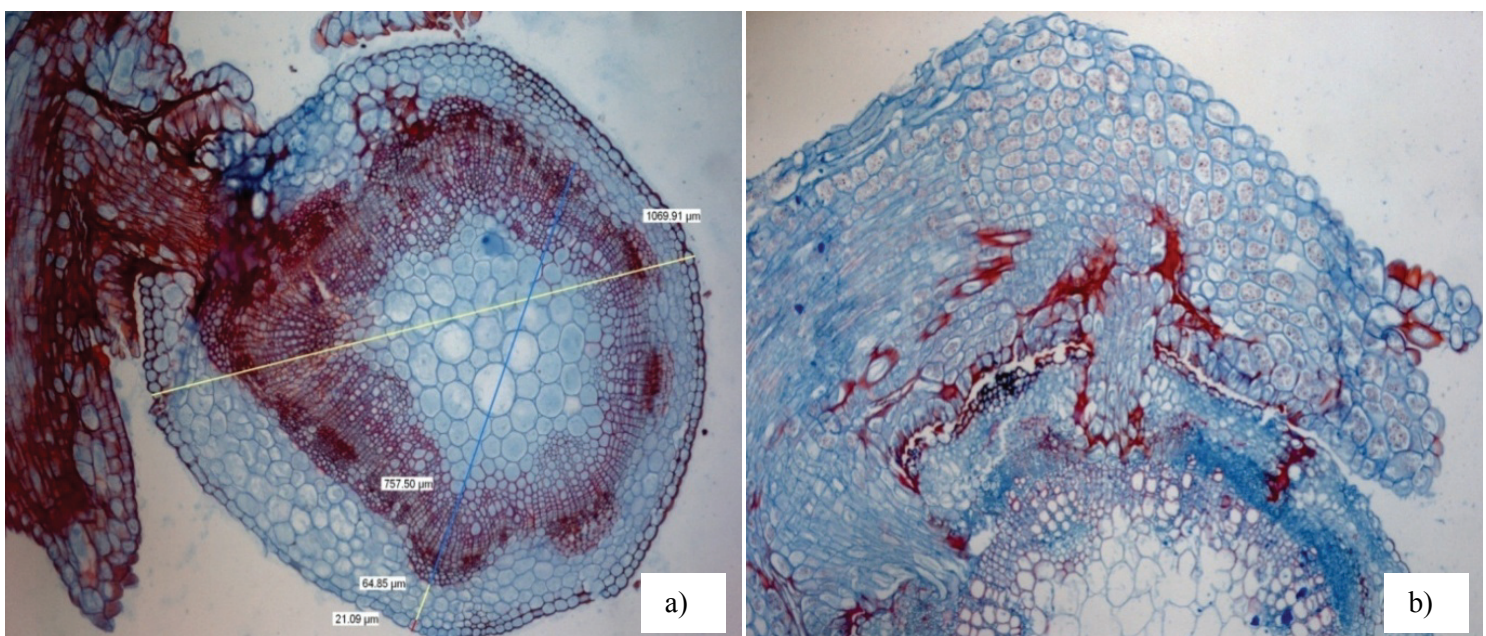

Figure 5. Haustorium "searching hyphae" of field dodder connecting to cortical parenchyma cells (a) and phloem tissue (b) of alfalfa stem (Sarić-Krsmanović, 2013)

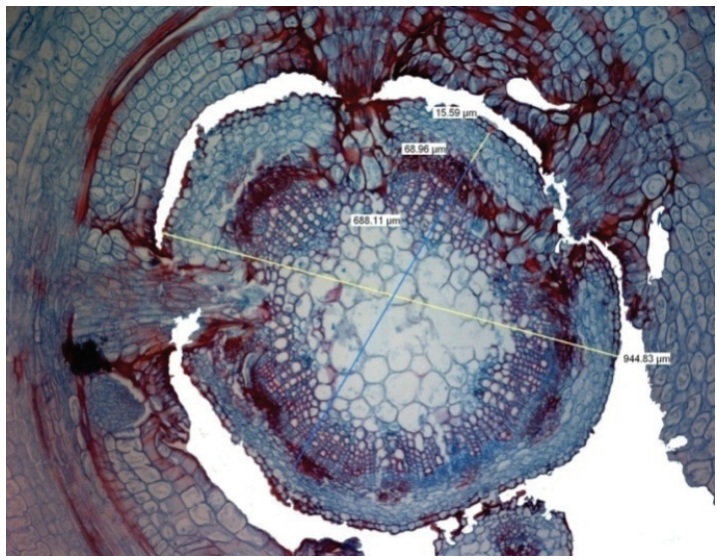

Figure 6. Field dodder haustoria (an example of hypersensitive reaction)

A number of studies have confirmed that species of the Cuscuta genus may attach to different parts of host plants. Apart from the stem as the primary site of parasite penetration, the petiole and leaf are the other most frequent points (Alkhesraji et al., 2000; Frost et al., 2003). Differences regarding the site and manner of attachment of a parasite to its host cannot be exclusively attributed to the variety of Cuscuta species. On the contrary, the mechanism of attachment often depends on different hosts of the same Cuscuta species. A variety of physical and physiological barriers (Al-Hammawandi, 1990; Perez et al., 2005) of the host plant may crucially influence the way a Cuscuta species connects to its hosts. Differences in the way epidermal cells of hosts are built (thickness), as well as the presence of cuticles and wax secreted onto the stem epidermal surface may also be the cause, while many plants, especially weeds, have such substances on the surface of leaf epidermis as well. Their presence is especially notable in grasses, which is believed to be the reason why members of that family have not been observed as field dodder hosts.

\section{CONCLUSION}

Cuscuta plants, being a generalist type of holoparasitic plants, interact with various hosts in different manner, and all Cuscuta species depend (absolutely) on host plants to complete their life cycle. Most hosts of Cuscuta species are passive; only a few hosts are known to show clear resistance (e.g. Ipomoea sp.). Unlike other weeds occurring in anthropogenic habitats that have been well-studies in their taxonomic, biological, ecological aspects, as well as their anatomical and physiological properties to some extent, the parasitic flowering species of the genus Cuscuta have been examined very scarcely despite the great damage that they are able to cause. More extensive research is required in order to develop new means for parasitic weed control. A basic research should identify new targets for control within the life cycle of the parasites and among their metabolic activities.

\section{ACKNOWLEDGEMENT}

We acknowledge the funding of the Ministry of Education, Science and Technology of the Republic of Serbia, Project III 46008. 


\section{REFERENCES}

Albert, M., Belastegui-Macadam, X., \& Kaldenhoff, R. (2006). An attack of the plant parasite Cuscuta reflexa induces the expression of attAGP, an attachment protein of the host tomato. Plant Journal, 48, 548-556.

Al-Hammawandi, F.S. (1990). A comparative anatomical study of relationship between Orobanche aegyptica Pers. and it's host plants. (Doctoral thesis), Science Collage, Salahaddin University, Iraq.

Alkhesraji, T.O., Aziz, F.M., \& Mahdi, N.B. (2000). Graniferous tracheary elements in Orobanchaceae. Diyala Journal of Science Research and Education (Iraq), 1, 190-205.

Baskin, C.C., \& Baskin, J.M. (1998). Seeds: Ecology, biogeography, and evolution of dormancy and germination. San Diego, CA: Academic Press.

Beliz, T. (1986). A revision of Cuscuta sect. Cleistogrammica using phenetic and cladistic analyses with a comparison of reproductive mechanisms and host preferences in species from California, Mexico, and Central America. (PhD dissertation). University of California, Berkeley, CA.

Benvenuti, S., Dinelli, G., Bonetti, A., \& Catizone, P. (2005). Germination ecology, emergence and host detection in Cuscuta campestris. Weed Research, 45(4), 270-278.

Benvenuti, S., Pompeiano, A., Macchia, M., \& Miele, S. (2002). Orobanche seed bank dynamics in tobacco by using a germination stimulant. In $12^{\text {th }}$ European Weed Research Society Symposium, Wageningen (pp 380-381). Dordrecht, Netherlands: Academic Publishers.

Birschwilks, M., Haupt, S., Hofius, D., \& Neumann, S. (2006). Transfer of phloem-mobile substances from the host plants to the holoparasite Cuscuta sp. Journal of Experimental Botany, 57(4), 911-921.

Costea, M., \& Tardif, F.J. (2006). The biology of Canadian weeds. 133. Cuscuta campestris Yuncker, C. gronovii Willd. ex Schult., C. umbrosa Beyr. ex Hook., C. epithymum (L.) L. and C. epilinum Weihe. Canadian Journal of Plant Science, 86(1), 293-316.

Dawson, J.H., Musselman, L.J., Wolswinkel, P., \& Dörr, I. (1994). Biology and control of Cuscuta. Reviews of Weed Science, 6, 265-317.

Dörr, I. (1968). Zur Lokalisierung yon Zellkontakten zwischen Cuscuta odorata und verschiedenen hiSheren Wirtspflanzen (Localization of cell contacts between Cuscuta odorata and different higher host plants). Protoplasma, 65(4), 435-448.

Dörr, I. (1969). Feinstruktur intrazellular wachsender CuscutaHyphen (Fine structure of intracellular growing CuscutaHyphae). Protoplasma, 67(2-3), 123-137.
Dörr, I. (1972). Der Anschluß der Cuscuta-Hyphen an die Siebröhren ihrer Wirtspflanzen (Contact of CuscutaHyphae with sieve tubes of Its host plants). Protoplasma, 75(1-2), 167-184.

Frost, A., Lopes-Gutierrez, J.C., \& Purrington, C.B. (2003). Fitness of Cuscuta salina (Convolvulaceae) parasitizing Beta vulgaris (Chenopodiaceae) grown under different salinity regimes. American Journal of Botany, 90(7), 1032-1037.

Garcia, M.A., \& Martin, M.P. (2007). Phylogeny of Cuscuta Subgenus Cuscuta (Convolvulaceae) based on nrDNA ITS and chloroplast trnL intron sequences. Systematic Botany, 32(4), 899-916.

Haidar, M.A. (2003). Characterization of the interaction between cryptochromes and phytochromes in blue light-induced coiling and prehaustoria development of dodder (Cuscuta campestris) seedlings. Annals of Applied Biology, 143(1), 57-62.

Haidar, M.A., Iskandarani, N., Sidahmed, M., \& Baalbaki, R. (1999). Response of field dodder (Cuscuta campestris) seed to soil solarization and chicken manure. Crop Protection, 18(4), 253-258.

Haidar, M.A., Orr, G.L., \& Westra, P. (1997). Effects of light and mechanical stimulation on coiling and prehaustoria formation in Cuscuta spp. Weed Research, 37(4), 219-228.

Haupt, S., Oparka, K.J., Sauer, N., \& Neumann, S. (2001). Macromolecular trafficking between Nicotiana tabacum and the holoparasite Cuscuta reflexa. Journal of Experimental Botany, 52(354), 173-177.

Heide-Jørgensen, H. S. (1991). Anatomy and ultrastructure of the haustorium of Cassytha-Pubescens R. Br. - I. The adhesive disk. Botanical Gazette, 152(3), 321-334.

Hibberd, J.M., \& Jeschke, W.D. (2001). Solute flux into parasitic plants. Journal of Experimental Botany, 52(363), 2043-2049.

Hibberd, J.M., Quick, W.P., Press, M.C., Scholes, J.D., \& Jeschke, W.D. (1999). Solute fluxes from tobacco to the parasitic angiosperm Orobanche cernua and the influence of infection on host carbon and nitrogen relations. Plant Cell Environment, 22(8), 937-947.

Holm, L., Doll, J., Holm, E., Pancho, J.V., \& Herberger, J.P. (1997). World weeds: Natural histories and distribution. New York: J. Wiley.

Hutchison, J.M., \& Ashton, F.M. (1979). Effect of desiccation and scarification on the permeability and structure of the seed coat of Cuscuta campestris. American Journal of Botany, 66, 40-46.

Hutchison, J.M., \& Ashton, F.M. (1980). Germination of field dodder (Cuscuta campestris). Weed Science, 28(3), 330-333.

Ihl, B., \& Wiese, K. (2000). Studien an Cuscuta reflexa Roxb.: VIII. Mechanische Haustorien-induktion an nichtwindenden Achsen des Parasiten. Flora, 195, 1-8. 
Jeschke, W.D., Rath, N., Baumel, P., Czygan, F., \& Proksch, P. (1994). Modelling the flow and partitioning of carbon and nitrogen in the holoparasite Cuscuta reflexa Roxb. and its host Lupinus albus L.: II. Flows between host and parasite and within the parasitized host. Journal of Experimental Botany, 45(6), 801-812.

Joel, D.M., Hershenhorn, J., Eizenberg, H., Aly, R., Ejeta, G., Rich, P.J.... Rubiales, D. (2007). Biology and management of weedy root parasites. Horticultural reviews, 33, 267-349.

Kojić, M., \& Vrbničanin, S. (2000). Parazitski korovi Osnovne karakteristike, taksonomija, biodiverzitet i rasprostranjenje, I: Vilina kosica (Cuscuta L.), Acta biologica Jugoslavica, seria G: Acta herbologica, 9(1), 21-29.

Koskela, T., Salonen, V., \& Mutikainen, P. (2001). Interaction of a host plant and its holoparasite: effects of previous selection by the parasite. Journal of Evolutionionary Biology, 14(6), 910-917.

Kuijt, J. (1969). The biology of parasitic flowering plants (pp 45-51). Barkeley, CA: University of California Press.

Lados, M. (1999). Effect of temperature, $\mathrm{pH}$ and host plant extract on the germination of Cuscuta trifolii and $C$. campestris seeds. Novenytermeles, 48, 367-376.

Losner-Goshen, D., Portnoy, V.H., Mayer, A. M., \& Joel, D.M. (1998). Pectolytic activity by the haustorium of the parasitic plant Orobanche L. (Orobanchaceae) in host roots. Annals of Botany, 81(2), 319-326.

Lyshede, O.B. (1984). Seed structure and germination in Cuscuta pedicellata with some notes on $C$. campestris. Nordic Journal of Botany, 4(5), 669-674. doi:10.1111/j.1756-1051.1984.tb01992.x

Lyshede, O.B. (1992). Studies on mature seeds of Cuscuta pedicellata and C.campestris by electron microscopy. Annals of Botany, 69(4), 365-371.

Marambe, B., Wijesundara, S., Tennakoon, K., Pindeniya, D., \& Jayasinghe, C. (2002). Growth and development of Cuscuta chinensis Lam. and its impact on selected crops. Weed Biology and Management, 2(2), 79-83.

Matković, A., Božić, D., Radošević, R., \& Sarić-Krsmanović, M. (2012). Uticaj viline kosice (Cuscuta campestris Yunck.) na anatomsku građu stabla lucerke (Medicago sativa L.) u uslovima sa i bez primene herbicida. In Zbornik rezimea radova XIV simpozijum o zaštiti bilja i IX kongres o korovima, Zlatibor (p 150). Belgrade, Serbia: Društvo za zaštitu bilja Srbije.

Nickrent, D.L. (2002). Plantas parásitas en el mundo. Part 2. In J.A. López-Sáez, P. Catalán and L. Sáez (eds.), Plantas Parásitas de la Península Ibérica e Islas Balears (pp 7-27). Madrid, Spain: Mundi-Prensa Libros, S.A.

Orr, G.L., Haidar, M.A., \& Orr, D.A. (1996). Small seed dodder (Cuscuta planiflora) phototropism toward farred when in white light. Weed Science, 44(2), 233-240.
Panetta, F.D., \& Lawes, R. (2005). Evaluation of weed eradication programs: The delimitation of extent. Diversity and Distribution, 11(5), 435-442.

Parker, C. (1991). Protection of crops against parasitic weeds. Crop Protection, 10, 6-22.

Parker, C. (2009). Observations on the current status of Orobanche and Striga problems worldwide. Pest Management Science, 65(5), 453-459.

Perez-De Luque, A., Rubiales, D., Cubero, J.I., Press, M.C., Scholes, J., Yoneyama, K.... Joel, D.M. (2005). Interaction between Orobanche crenata and its host legumes: Unsuccessful haustorial penetration and necrosis of the developing parasite. Annals of Botany, 95(6), 935-942.

Piehl, M. A. (1963). Mode of attachment, haustorium structure, and hosts of Pedicularis canadensis. American Journal of Botany, 50, 978-985.

Press, M.C. \& Phoenix, G.K. 2005. Impacts of parasitic plants on natural communities. New Phytologyst, 166(3), 737-751.

Rath, G. C., \& Mohanty, S. S. (1987). Production of haustoria of Cuscuta chinensis in contact with glass surface. Indian Phytopathology, 40, 415-416.

Runyon, J.B., Mescher, M.C., \& de Moraes, C.D. (2006). Volatile chemical cues guide host location and host selection by parasitic plants. Science, 313(5795), 1964-1967.

Runyon, J.B., Mescher, M.C., Felton, G.W., \& De Moraes, C.M. (2010). Parasitism by Cuscuta pentagona sequentially induces JA and SA defence pathways in tomato. Plant Cell \& Environment, 33(2), 290-303.

Salimi, H., \& Shahraeen, N. (2000). Study on comparison of seed dormancy and germination of three species of dodder. Rostaniha, 1, 33-36.

Sarić-Krsmanović, M. (2013). Biologija viline kosice (Cuscuta campestris Yunck.) i mogućnosti njenog suzbijanja (Biology of field dodder (Cuscuta campestris Yunck.) and its control) (Doktorska disertacija). Univerzitet u Beogradu, Poljoprivredni fakultet.

Sarić-Krsmanović, M., Božić, D., Kresović, M., Radivojević, Lj., \& Vrbničanin, S. (2013a). Effect of Cuscuta campestris on the nitrogen, phosphorus and potassium content in alfalfa and sugar beet. In Abstract book $1^{\text {st }}$ International Conference on Plant Biology, 20 $0^{\text {th }}$ Symposium of the Serbian Plant Physiology Society, Subotica, Serbia (p 83).

Sarić-Krsmanović, M., Božić, D., Pavlović, D., Radivojević, Lj., \& Vrbničanin, S. (2013b). Temperature effects on Cuscuta campestris Yunk. seed germination. Pesticides and Phytomedicine, 28(3), 187-193.

Sarić-Krsmanović, M., Božić, D., Radivojević, Lj., Gajić Umiljendić, J., \& Vrbničanin, S. (2016). Impact of field dodder (Cuscuta campestris Yunk.) on physiological and anatomical changes in untreated and herbicide-treated alfalfa plants. Pesticides and Phytomedicine, 31(3-4), 115-120. 
Sarić-Krsmanović, M., Rančić, D., \& Radivojević, Lj. (2012): Morfološke, anatomske i fiziološke promene na lucerki i šećernoj repi napadnutim vilinom kosicom (Cuscuta campestris Yunck.). In Zbornik rezimea radova XIV simpozijum o zasttiti bilja i IX kongres o korovima, Zlatibor, Srbija (130-131). Beograd, Srbija: Društvo za zaštitu bilja Srbije.

Srivastava, S., Nighojkar, A., \& Kumar, A. (1994). Multiple forms of pectin methylesterase from Cuscuta reflexa filaments. Phytochemistry 37(5), 1233-1236.

Stefanović, S., Kuzmina, M. \& Costea, M. (2007). Delimitation of major lineages within Cuscuta subgenus Grammica (Convolvulaceae) using plastid and nuclear DNA sequences. American Journal of Botany, 94(4), 568-589.

Stewart, G.R. \& Press, M.C. (1990). The physiology and biochemistry of parasitic angiosperms. Annual Review of Plant Physiology and Plant Molecular Biology, 41, 127-151.

Swift, C. (1996). Cuscuta and Gramica species - dodder a plant parasite. Fort Collins, US: Colorado State University Cooperative Extension.

Tada, Y., Sugai, M., \& Furuhashi, K. (1996). Haustoria of Cuscuta japonica, a holoparasitic flowering plant, are induced by the cooperative effects of far-red light and tactile stimuli. Plant and Cell Physiology, 37(8), 1049-1053.

Tsivion, Y. (1981). Suppression of axillary buds of its host by parasitic Cuscuta: I. Competition among sinks and indirect inhibition. New Phytologist, 87(1), 91-99.
Vail, S.L., Dailey, O.D., Blanchard, E.J., Pepperman, A.B., \& Riopel, J.L. (1990). Terpenoid precursors of strigol as seed germination stimulants of broomrape (Orobanche ramosa) and witchweed (Striga asiatica). Journal of Plant Growth Regulation, 9, 77-83.

Vaughn, K.C. (2003). Dodder hyphae invade the host: A structural and immunocytochemical characterization. Protoplasma, 220(3-4), 189-200.

Vaughn, K.C. (2002). Attachment of the parasitic weed dodder to the host. Protoplasma, 219(3-4), 227-237.

Vrbničanin, S., Malidža, G., Stefanović, L., Elezović, I., Stanković-Kalezić, R., Marisavljević, D.... Gavrić, M. (2008). Distribucija nekih ekonomski štetnih, invazivnih i karantinskih korovskih vrsta na području Srbije. II deo: Prostorna distribucija i zastupljenost devet korovskih vrsta na području Srbije. Biljni lekar, 36(6), 408-417.

Vrbničanin, S., Sarić-Krsmanović, M. \& Božić, D. (2013). The effect od field dodder (Cuscuta campestris Yunck.) on morphological and fluorescence parameters of giant ragweed (Ambrosia trifida L.). Pesticidi i fitomedicinal Pesticides and Phytomedicine, 28(1), 57-62.

Wolswinkel, P. (1974). Complete inhibition of setting and growth of fruits of Vicia faba L. resulting from the draining of phloem system by Cuscuta species. Acta botanica neerlandica, 23, 48-60.

Yoder, J.I. (1999). Parasitic plant responses to host plant signals: a model for subterranean plant-plant interactions. Current Opinion in Plant Biology, 2(1), 65-70.

Yuncker, T. G. (1932). The genus Cuscuta. Memoirs Torrey Botanical Club, 18(2), 109-331.

\section{Vilina kosica - životni ciklus i interakcija sa domaćinom}

\section{REZIME}

Vilina kosica je parazitska cvetnica koja se vezuje za stablo i lišće biljaka domaćina i parazitira značajan broj ekonomski značajnih vrsta, korove i ukrasno bilje. Postoje različite mere koje se mogu preduzeti za suzbijanje viline kosice, počev od preventivnih (čist semenski materijal, otporne sorte), preko mehaničkog uklanjanja (košenje, ručno uklanjanje) do korišćenja herbicida, ali je veoma teško postići efektivnu kontrolu ove parazitne cvetnice, zbog prirode vezivanja sa biljkom domaćinom. Za pravljenje dobre strategije u suzbijanju viline kosice pored integrisanja gore pomenutih mera, neophodno je i poznavanje njenog razvoja i životnog ciklusa.

Ključne reči: Vilina kosica; Cuscuta; Životni ciklus; Domaćin 